\title{
SHAMANISM IN A POSTMODERN AGE
}

\section{Mihaly Hoppal}

A few decades ago it was generally held that shamanism in Siberia had ceased to exist and belonged among the worthless ideological memories of the past. This opinion prevailed both in the communist Soviet Union which still existed at that time, as well as in other parts of the world, in the western capitalist countries. In the mid20th century and even in the sixties and seventies both ideological systems still lived in the fever of development. The most important ideal in those decades was that of the modern world that could be created through development.

The concept of modern has been one of the most frequently repeated keywords of the 20th century and consequently had almost magical power. It was imbued with positive content, in part because it was associated with development - mainly technical development - and in part because it meant rejection of the tradition of earlier periods: the repudiation, denial and destruction of tradition of all kinds.

The 20th century has often been called the age of revolutions and revolutionary change. But this label hid what was one of the very characteristic features of the process: modernity was always accompanied by destruction. In most cases, transformation meant the destruction of the earlier structures. Parallel with the technical development, the social structures changed, especially in those cases where the transformation was urged or even directed by political and ideological forces. It was perhaps folk culture that was most strongly affected by these changes. In the eyes of the militants of modernity, cultural traditions were the most hated enemy. This was especially true in Siberia where the archaic beliefs and mythology, the heroic epic and narrative tradition preserved the identity of the ethnic minorities. This meant that shamanism was among the elements of traditional culture to be eradicated.

In short, the transformation that was carried out in the name of modernity and so-called development was directed against tradition. However successful this ideology of modernity may have appeared for decades, by the late seventies and even more in the eighties and nineties its shortcomings, failure and unavoidable revision became obvious. It was found that the forced industrial development had not only brought unquestionable achievements and created a certain degree of prosperity: it had also caused enormous environmental pollution. The disruption of the traditional local communities and the rejection of cultural traditions (religions and rites) resulted in moral uncertainty (and in rising crime rates).

As a reaction, a return to traditions can be quite clearly observed in the post-modern age. This is especially true in post-communist Russia, among the small ethnic groups in the area of today's Siberia.

A quarter of a century after the studies in Shamanism in Siberia (Dioszegi-Hoppál eds. 1978) were written, the emergence of a trend that could be called post-modern shamanism can now be seen. The author of this article had the opportunity to observe a number of forms of this post-traditional 
shamanism. In the following the main types of Eurasian shamanism today are presented on the basis of experiences gained in the field. Naturally, the typology is not final; it is in need of expansion and refinement but for the time being it can be regarded as a good representation of the phenomena. There is a need for such a typology because most of the colleagues deal with the old shamanism bud neglect the phenomena of today's (post-)modern shamanism.

Two main classes of phenomena can be distinguished: one contains those cultures in which shamanism as an autochthonous phenomenon has survived more or less continuously up to the present, while the other group of phenomena consists of neo-shamanism (or urban shamanism) which has arisen mainly in an urban context. The first group can be divided into a further two subgroups. The first comprises the cultures where shamanism survived and was kept alive by tradition practically without interruption, while the second contains the peoples and forms of shamanism where the shamans had been almost eliminated but escaped at the last minute.

Perhaps the best point to begin with are the Koreans. Korea lies at the eastern extremity of the Eurasian continent, between China and Japan and has shaped a wholly autonomous culture. An important feature of this autochthonous culture is shamanism (musok). Scholars hold many different opinions on Korean shamanism, its character and components, but they agree on one thing: shamanism represents the oldest stratum in Korean folk religion (Carter-Covell 1981; Covell 1986; Guisso-Yu 1988; Kendall 1987, 1988).

All aspects of Korean culture, including religion, are imbued with the ideology of Buddhism and Neo-Confucianism. Nevertheless a stratum - presumably originating from Central Asia - can be found underlying these: the institution of the king-shaman which can be traced back to the Silla Kingdom (8th century). In general, right up to the present, beside the various Christian missionary activities and the "new religion" movements (such as the world religion founded by Reverend Moon), the strongest trend is the everyday religious practice performed by shamanesses (mudang) which Korean colleagues classify in the category of shamanism. Whatever the case, it is a fact that today's over-ornamented and highly elaborate shaman ceremony, somewhat resembling a dramatic theatre performance, wholly determines the everyday religious life of the Koreans, a people producing and exporting the most advanced technology at the end of the 20th century. The author personally visited Seoul three times and had a number of opportunities to take part in the ceremonies $(k u t)$ which were directed by shamanesses. These ceremonies lasting several hours not only convinced me of their very powerful stress-relieving effect, but also that they ensure cultural continuity from one generation to the next within the culture. The shaman ceremony has become an important vehicle for the transfer of tradition since it serves to maintain a "direct « relationship and communication with the ancestors. (The ceremony known as chinogwikut, which serves to evoke the spirit of deceased ancestors, in particular has such a function. The author participated in such a full-day ceremony in Inchon, a suburb of Seoul, in 1994.) Although many different cultural elements are found in the Korean shaman ceremonies (in addition to those already mentioned, elements of contemporary life have also been incorporated), their principal characteristic is nevertheless cultural continuity since the operation of the mudang in South Korea has not been exposed to any violent influence. Naturally, the situation is different in the North where the communist ideological hegemony did not tolerate systems of religious beliefs of any kind. In the South, in contrast, shamanism is seen as a traditionalising expression of national culture and its most outstanding representatives are valued as a 'national treasure' and used for the strengthening of national identity.) 
It is interesting to observe that something similar happened in the field of cultural continuity in Manchuria, one of the regions of the People's Republic of China inhabited by different nationalities. The Manchu nationality is one of the larger minorities in today's China (four and a half million) and has an especially strong historical awareness because they gave the emperor of the last imperial dynasty. In addition, they live in a compact group in Jilin province and shamanism has very ancient traditions among their religious notions: it takes a special form of clan shamanism and one of its most important functions is to maintain ethnicity, family and kinship relations on the occasion of large family gatherings (Fu 1993; Guo 1993).

Recent ethnographic documentary film made in the early nineties (cf.: Hoppál 1992:191-196, and Shi 1993:49) show that this is a living tradition. A number of shamans appeared simultaneously at larger gatherings and the series of ceremonies were held in conjunction with clan prosperity. The fact that for centuries the Manchu shamans had hand-written ceremonial books (Pozzi 1992, Stray 1992) almost certainly contributed to the continuous preservation of the Manchu shaman traditions. (In 1993, I personally visited Manchuria where I met an elderly shaman who also had a handwritten ceremonial book. Hoppál 1994; a photograph of the shaman can be seen on the cover.)

In China, Manchu shamanism survived the period of communist ideological repression relatively well and in recent years it has been possible to publish a growing number of books and studies (cf.: Shi 1993). Researchers of Manchu origin (Fu 1993; Guo 1995) also reported that this tradition has a number of followers and active practitioners among the younger generation too. On the other side of the Amur river in the Far-Eastern part of the Russian empire live the small Tunguz people from whose language the word shaman is also derived. In 1993 I spent time among the Nanai people and found that from the point of view of typology, the shamanism there can be regarded as essentially continuous. The elderly shamaness - Lindza Beldi - who is illiterate but nevertheless (or precisely for that reason) preserves a rich store of shaman narrative lore, is definitely a fact of the continuity of tradition. In the remote corner of the empire, in the small village beside the Amur the local population needed the help of the shamans which is why they were not persecuted excessively during the period of communism.

This example does not mean that shamans were not persecuted more strongly elsewhere. In the case of the Yakuts, for example, the matter of shamanism was treated as a political issue right from the earliest Soviet times practically up to the present (Balzer 1990, 1993). There is nothing surprising about this since the shamans were the ones who preserved their traditions, the old beliefs, oral epic tradition and mythology. By practising their art almost daily they ensured the continuous existence of folk culture, and therefore it is not by chance that from the thirties the local institutions of repression began to persecute them. Many hundreds of shamans ended their lives in concentration camps or forced labour camps (Gulags).

In spite of that, they were not entirely wiped out and when in the early nineties the restrictions of ideological repression began to ease, they immediately surfaced and while earlier they had only been taken to folklore festivals, in the last few years they have begun to work again, engaged mainly in healing. In 1992, when I visited the Sakha Republic, I found that the previously persecuted Yakut shamans (oyuun, udagan) had appeared again and were active as healers. They even held a theatre performance in the local National Theatre for the participants in the international conference of shamanism, in which actors played the part of the shamans in an attempt to preserve the continuity of the ethnic poetic tradition. This is because the great majority of the Sakha (Yakut) 
population no longer speak the language of their ancestors. The theatre is an excellent means for reviving certain elements of folk culture and in particular for keeping alive songs and narrative traditions. At the same time, the Yakut scholar colleagues immediately recognized the ideological significance of shamanism as well (Gogoljev et al 1992).

We found similar phenomena in Tuva where, after long decades of shaman persecution, what could be called a renaissance of shamanism can be observed in 1995. The earlier communist political leaders, who are now the chief supporters of nationalism, support lamaism in the republic in the same way as the revival of shamanism. It should be noted that in the early thirties there were even more shamans than lamas working to preserve the spiritual health of the people (Djakonova 1978), although the two forms of religious practice coexisted peacefully.

The situation is especially fortunate in Tuva because the study of shamanism there has long been in the hands of expert researchers (V. P. Djakonova, S. I. Vajnshtejn and the local scholar-researcher M. B. Kenin-Lopsan - see his most recent works giving a general summary on Tuva shamanism Kenin-Lopsan 1993, 1996). A large body of collected material is available for further research, as well as for general enquirers. Mongus Kenin-Lopsan has played a considerable part in keeping this interest alive. He is not only an ethnographic collector but also a writer, one of those best acquainted with Tuva folklore traditions, a living classic, and president of the social organization known as Düngür. The drum used by Tuva shamans is called düngür, and this word was adopted as the name of the federation whose members are healing shamans working in Kyzyl, the capital, carrying out their activity of divination, diagnosing and healing in a perfectly matter-of-fact way in today's modern (post-modern or post-communist) urban environment.

Current Tuva shamans, many of whom I have had the good fortune to meet, are characteristic figures in the history of shamanism in Siberia: many of them were imprisoned in the fifties, spending years in labour camps, and despite that they are again practising their craft. While speaking to them, their commitment and readiness to help could clearly be felt, as well as their pride in the fact that they are preserving and continuing genuine folk (ethnic) traditions.

The situation is not so straightforward in the case of the Finno-Ugrian (Uralic) peoples living in the northern regions of the Russian Federation. Shamanism was never as strong there as among the Turkic-speaking peoples of southern Siberia. These small communities which now number only a few thousand persons were always more vulnerable to Russian cultural influence and the danger of russification. From the typological viewpoint it is the shamanism of these ethnic groups which perhaps came closest to complete oblivion (Balzer 1987). Nevertheless, signs of an interesting revival have begun to appear among the northern peoples and some researchers regard shamanism as "an expression of the northern identity« (Pentikäinen 1995).

The shaman tradition found among the Khanty, an Ob-Urgian people, has taken an interesting course in recent decades. While the earlier literature on the subject essentially regarded the phenomenon as no longer living, ethnographic documentary films made on the bear ceremonies of the Ostyak ethnic group, mainly the work of Lennart Meri (for a description, see Hoppál 1992:184187) drew attention to one of the last surviving shamans. As a consequence, a number of researchers made trips to visit the family and a number of studies have been published from the research done (Kerezsi 1993, 1995). 
A similar case can be observed with one of the renowned shaman families of the Nganasan, a small ethnic group living on the Taimyr peninsula. For generations the community's shamans came from the members of the Ngamtusuo clan. They have preserved this role right up to the present (Helimsky-Kosterkina 1992). In the seventies Lennart Meri made a film of the last great shaman, Demnime, and a number of other films have also been made since then. Practically all the relatives have now joined in the chain of folklorism, reproducing in theatre-like form the songs and art of the shaman father. On the one hand this activity is entirely authentic since they are repeating songs learnt from the authentic source (Dobzhanskaya 1995), but on the other hand it is not entirely authentic since the songs are performed and the drum produced outside the ritual (sacral) context. Not to mention the fact that the family members playing the part of the shaman are no longer initiated shamans and as such do not even have the right to perform the sacred songs. However, it is in this way that tradition finds a means of surviving, independently of the political and social environment.

The researcher has a tendency to proclaim that this is the last chapter in the history of shamanism in Siberia. When in the summer of 1994, among the performers at a folklore festival in southern France I came across a small group formed by members of the Kosterkin family, dressed in Siberian fur winter-costume to give a short performance in the summer heat, one may declare that this is the end of "shamanism in Siberia«. But perhaps it is not really the end, because it is precisely such festival invitations and opportunities to appear on film and television which lead the members of the younger generation to carry on the tradition, as performers enacting the ancient ritual. Naturally, this is an entirely different shamanism from that discussed in the studies. The representatives of neo-shamanism have appeared in Siberia, as in other parts of the world and their role is just as deserving of attention as that of their predecessors (Kiva 1995; Sarv 1995). However, an examination of this would lead very far, although cultural anthropology research cannot avoid investigating the new phenomena of shamanism in the future either.

\section{References}

Balzer, Majorie 1987. Behind Shamanism: Changing Voices of Siberian Khanty Cosmology and Politics. Social Science and Medicine 24:12, pp. 1085-1093.

Balzer, Majorie 1993. Shamanism and the Politics of Culture. Shaman 1:2, pp. 71-96. Balzer, Majorie (ed.) 1990. Shamanism: Soviet Studies of Traditional Religion in Siberia and Central Asia. Armonk, NY:M.E. Sharpe.

Carter-Covell, Jon 1981. Korea's Cultural Roots. Seoul: Moth Hous-Hollym.

Covell, Alan 1986. Folk Art and Magic: Shamanism in Korea. Seoul: Hollym.

Dioszegi, V. \& Hoppál, Mihály (eds.) 1978. Shamanism in Siberia. Budapest: Akademiai Kiado

(Selected Reprints edited by M. Hoppál. Bibliotheca Shamanistica vol. 2. Budapest: Akademiai

Kiado 1996).

Djakonova, V. P. 1978. The Vestments and Paraphernalia of a Tuva Shamaness. In: Dioszegi, V. \& Hoppál, M. (eds.). Shamanism in Siberia, pp. 325-379. Budapest: Akademiai Kiado.

Dobzhanskaya, Oksana 1995. The Music in the Nganasan Shaman Ritual. In: Kõiva, M. \& Vassiljeva, K. (eds.). Folk Belief Today, pp. 51-56. Tartu: Estonian Academy of Sciences.

$\mathrm{Fu}$, Yuguang 1993. The Worldview of the Manchu Shaman. In: Hoppál, M. et al. (eds.) Shamans and Cultures, pp. 240-248. Budapest-Los Angeles: Akademiai - ISTOR Books vol. 5. 
Gogoljev, A. I. et. al. (eds.) 1992 Shamanyzm kak religija: Genezis, Rekonstrukcija, Tradicii (Shamanism as Religion: Genesis, Reconstruction, Tradition) Yakutsk: Yakutskij Gos. Univ. Guisso, Richard W. I. \& Yu, Chai-shin (eds.) 1988 Shamanism: The Spirit World of Korea Berkeley: Asian Humanities Press.

Guo, Shuyun 1993. Social Functions of the Manchu Shaman. In: Hoppál, M. et al (eds.) Shamans and Cultures, pp. 249-257. Budapest-Los Angeles, Akademiai - ISTOR Books vol. 5.

Helimsky, E. A. \& Kosterkina, N. T. 1992. Small Seances with a Great Nganasan Shaman.

Diogenes No. 158, pp. 39-55.

Hoppál, Mihály (ed.) 1992. Ethnographic Films on Shamanism. In: Siikala, A. L. \& Hoppál, M.(eds.) Studies of Shamanism, pp. 182-196. Helsinki-Budapest: Finnish Anthropological Society - Akademiai Kiado.

Hoppál, Mihály (ed.)1994. Schamanen und Schmanismus. Augsburg Pattloch.

Kendall, Laurel 1987. Shamans, Housewives, and Other Restless Spirits. Honolulu: University of Hawaii Press.

Kendall, Laurel 1988. The Life and Hard Times of a Korean Shaman. Honolulu: University of Hawaii Press.

Kenin-Lopsan, M. B. 1993. Magija Tuvinszkikh Shamanov. (The Magic of Tuva Shamans). Kizik: Novosti Tuva.

Kenin-Lopsan, M. B. 1996. Shamanic Myths and Hymns from Tuva. Selected and edited by Hoppál, M. Budapest: Akademai ISTOR Books vol. 6.

Kerezsi, Agnes 1993. The Eastern-Khanty Shamanism. In: Hoppál, M. \& Paricsy, P. (eds.) Shamanism and Performing Arts, pp. 97-106. Budapest: Ethnographic Institute.

Kerezsi, Agnes 1995. Music Instrument in the Ritual Ceremonies on the Ob-Ugrians. In: Kõiva, M. \& Vassiljeva, K. (eds.) Folk Beliefs Today, pp. 182-188. Tartu: Estonian Academy of Sciences. Kõiva, Mare 1995. From Incantations to Rites. In: Kõiva, M. \& Vassiljeva, K. (eds.) Folk Beliefs Today, pp. 215-236. Tartu: Estonian Academy of Sciences.

Pentikäinen, Juha 1995. The Revival of Shamanism in the Contemporary North. In: Kim, Taegon \& Hoppál, M. (eds.) Shamanism in Performing Arts, pp. 263-272. Budapest: Akademiai Kiado.

Pozzi, Alessandra 1992. Manchu-Shamanica Illustrata. Wiesbaden: Otto Harrassowitz.

Sarv, Vaike 1995. The Complicated Role of a Soviet Shaman. In: Kõiva, M. \& Vassiljeva, K. (eds.) Folk Beliefs Today, pp. 434-438. Tartu: Estonian Academy of Sciences.

Shi, Kun 1993. Shamanistic Studies in China: A Preliminary Survey of the Las Decade. Shaman $1: 1$, pp. 47-57.

Siikala, A. L. \& Hoppál, M. 1992. Studies on Shamanism. Helsinki-Budapest: Finnish Anthropological Society - Akademiai Kiado. Ethnologica Uralica vol. 2.

Stray, Giovanni 1992. Das "Schamanenbuch« der Sibe-Mandschuren. Wiessbaden: Otto Harrassowitz. 